Jan Kubik

\title{
How to think about 'area' in Area Studies?
}

Forthcoming in 2019 in Z. Milutinovoc, ed. The Rebirth of Area Studies: Challenges for History, Politics and International Relations in the 21 st Century. I.B. Tauris.

\section{Contextual holism to the rescue}

Building on my earlier essay where I argued that the best work on post-communism has shown at least some features of what I called contextual holism, I am beginning to develop here a novel approach to Area Studies. Most people reflecting on this topic concentrate their efforts on the word 'studies' and usually attempt to define the approach's specific methodology (for example interdisciplinarity), reconstruct its intellectual genealogy, and identify its political and ideological entanglements. My investigation is driven by unhappiness with what appears to be imprecise and unexamined uses of the term 'area.' If the area approach means the rejection of universalism and a postulate of studying problems in the context of relevant cultures and histories, based on the fluent knowledge of pertinent languages - it is not clear why this approach is called 'Area' Studies and not, say, 'cultural,' 'local,' or 'contextual' studies. In short, why call it 'area'?

Contextual holism, an approach I started defining several years ago while working on postcommunist transformations in Eastern and Central Europe, is based on five principles or epistemological directives: (1) constructivism, (2) relationism ('weak' structuralism), (3) historicism, (4) attention to scale, and (5) focus on informality (formal-informal hybrids).

Constructivism postulates that the manner in which people conceptualize, model, or envision the world around them matters for what they do (how they act). The ontology of constructivism is anti-naturalist (the social world is different from the natural world), thus the methodology consistent with this position requires interpretation (for example, of the meaning people attach to the actions of others). Scholars who agree with an (anti-naturalist) assumption that the signifying process through which people build models of the world has political relevance, proceed to study how such models are constructed, transmitted, maintained, and received, and how this whole machinery of cultural construction influences, and is influenced by, political and economic processes. The so-called Thomas Theorem is the most succinct articulation of the basic premise of constructivism: 'If men define situations as real, they are real in their consequences.' ${ }^{1}$ The concept of situation will be central in my examination of an area, in this case Central Europe, 'from the native point of view.' It is one of the key concepts of symbolic interactionism, ${ }^{2}$ a branch of Sociology that traces its roots to Thomas's work. It was also used by the eminent Polish art historian, Mieczysław Porębski, one of my teachers. In an extremely insightful essay, 'Polishness as a Situation,' he offered the following definition: 'The situation called Polishness is conditioned by the existence of a spiritual community - partially territorially coherent, partially dispersed in a diaspora - that coalesces around specific historically conditioned symbols. This spiritual community defines its continuance in terms of these symbols and derives from them the perpetuation of continuance and dignity.' ${ }^{3}$ Porębski enumerates and briefly characterizes several symbols that help to establish and maintain Polishness: locations, books, images, sounds, tastes, and colours. He identifies also the state of endangerment as a powerful and reoccurring factor influencing Polishness as a situation. In my analyses I will emphasize that there usually are 
several ways in which members of a given group define their situation. The situation, like almost every other element of culture, is a contested notion or image - as the 'natives' rarely, if ever, agree how to define it. This is certainly true when it comes to defining the situation through the lens of the the concept of 'area'.

Relationism calls for an approach to the socio-political reality that tries to avoid the extremes of individualism and holism or, in a somewhat different formulation: agency and structure. Quite a few scholars have come to realize that this seemingly intractable duality cannot be sidestepped but must be unpacked and theorized - even if imperfectly - if we hope to improve our understanding of many important processes occurring in any region. ${ }^{4} \mathrm{McFaul}$, for example, observes that while 'actor-centric, cooperative approaches to democratization offer a useful starting point for explaining post communist regime transformations,' they focus excessively on elites and their deals, ${ }^{5}$ and downplay the role of popular mobilization that - as we know from the literature on social movements - must be analysed as a process in which agency and structural constraints influence each other. Relationism, as I see it, postulates therefore to study the interaction between structure and agency iteratively and it emphasizes the significance of networks. Here, I am interested in networks an 'area' is constituted by and/or embedded in. It also postulates to pay careful attention to various contexts, as approaches excessively focused on agency (particularly more formalized ones) do not provide sufficient tools to account for the various contexts within which actors act. ${ }^{6}$

In an influential essay on democratic transitions, Schmitter and Karl argue that the significance of actors' agency varies, depending on the phase of the process. They see a heightened role of agency during the transition to a new system, but structural factors become more significant during consolidation. As they put it, during transition the role of 'courageous individuals' and contingency are dominant, ${ }^{7}$ but a student of consolidation must shift attention to structural factors such as 'capitalist class conflicts, long-standing cultural and ethnic cleavages, persistent status conflicts and international antagonisms.' In brief, researchers must retool as they move from studying transition, which is underdetermined, to studying consolidation, which is overdetermined. ${ }^{8}$ In the phase of transition (before the regime breakthrough), elite actors strategize and act often in highly unpredictable and rapidly changing situations. But during regime consolidation the role of elite's actions declines in relative importance. Now much depends on what non-elite actors do in the dramatically changed situations, how they respond to the new institutional environment 'engineered' by the elites in a top-down manner. In their actions non-elite actors tend to be constrained by their socio-economic structural location and a reservoir of narratives drawn from their 'cultures of reference' that are often local. In such narratives elements of novelty are intertwined with the resurrected fragments of 'usable pasts' that often contain more or less stereotypical images of what 'our area' really is all about, what the historical legacies that shape its culture are, and how 'we,' as that the area's agents are supposed to act.

In sum, relationism postulates to merge sensitivity to a historically established set of constrains, including dominant or rising in a given culture narratives, with a contextualized study of agency (or the study of contextualized agency), particularly actors' efforts to build, protect, or resist being included in various networks. Often, empirical lenses need to be focused on concrete, localized, national, or area-bound communities of discourse where common definitions of the situation are formulated. The creation and maintenance of area networks is facilitated when such 
definitions include representations of the 'area' that actors then employ in their dealings with 'others,' particularly those who are construed as being 'outsiders' to 'our' area. ${ }^{9}$

The third building block of contextual holism, historicism (or historicizing), is not uniform as there are at least four separate ways to introduce history to the study of contemporary issues. The first is to debate the relative causal significance of historical and contemporary factors in the explanation of today's phenomena. The second is related to establishing sufficiently deep causal chains in explaining studied processes. ${ }^{10}$ The third revolves around the task of properly historicizing the studied phenomena and reconstructing the actors' cultural worlds from within they were acting, without imputing to them motivations and concerns that did not exist at the time of action. Fourth is to study the formation of legacies, whose cultural layer is not simply 'inherited' from the past, but is constructed by the actors acting in the present. ${ }^{11}$ The study of historical memory and its role in postcommunist political battles is a good example of this type of historicizing approach. For example, there is an emerging body of work on Central Europe as a distinct memory area.

The fourth principle of contextual holism, attention to scale, alerts us to the fact that the manner in which a given political, economic, or cultural process unfolds depends on its location in the whole system. The rhythms and mechanisms of change at the national level can be quite different from their counterparts occurring at the local, regional, or area levels. State socialism was perhaps the most powerful standardizing and homogenizing machine in history, yet regional differences and local specificities did not disappear completely. Actually some carefully monitored cultivation of subnational traditions was officially tolerated and not infrequently financed by the party-state. After the fall of state socialism, regionalism and localism exploded as cultural phenomena and the renaissance of subnational politics, often spurred by the devolution of power and decentralizing administrative reforms, commenced. These processes and their consequences need to be carefully studied as the official, 'national' discourses on belonging or not to a specific area may be quite different from the discourses proposed by regional or local actors, who may, for example, see their region as a meaningful part of some area like Central Europe, while downplaying the strength of their region's embeddedness in a nation state. This illustrates well one of the key points of this essay: an image of an area, such as Central Europe, appears in specific discourses propounded by concrete actors and influences their thoughts and actions to various degrees and with consequences that very much depend on specific cultural and political contexts within which such discourses are propagated.

According to the fifth and final premise of contextual holism in each part of the world much action transpires at the interstices between official structures and informal networks. This means that in order to understand what is going on we need to investigate the context-specific mix (hybrid) of formal and informal mechanisms, as is convincingly argued by Guha-Khasnobis, Kanbur, and Ostrom. ${ }^{12}$ To illustrate the necessity of studying such mixes it is enough to reflect for a moment on the nature of state-socialism. It would not have survived as long as it did had it not been for extensive informal economic networks propped up by massive informal (unofficial) cultures. Such networks often developed into complex social worlds that made surviving communism possible. Informality provided a crutch that sustained the state socialist economy, but - paradoxically - it also contributed to the system's demise by nourishing anti-regime movements. ${ }^{13}$ At least in the pioneering countries, such as Poland and Hungary, post-communism emerged not out of the totalitarian barren land of suppressed society, but rather from a beehive of 
activity in a post-totalitarian system, where people organized in semi-official and unofficial sectors of the economy, clandestine political spaces, and/or private networks. Not surprisingly, the legacy of informality is extensive and deeply rooted in many areas of life. For some observers, this 'unwanted' and 'damaging' legacy of state socialism is a burden that slows down post-communist societies in their efforts of becoming 'normal;' ${ }^{14}$ but for others it is rather a blessing in disguise as it helps people navigate the uncertain postcommunist reality. It seems to be both.

Two points regarding informality are central to my argument for the usefulness of contextual holism in understanding the significance of area, in this case Central Europe. First, it is important to see informality not as an unwelcome legacy of the communist system or an undesired byproduct of the new capitalist/democratic system, but rather as an inescapable albeit functional component of the transitory process. Very often people need to resort to informal mechanisms to survive or advance in life and that includes developing the ways of imagining the social world around them that are often substantially different from the official views. The way people construe 'their' area, a unit bigger than the national state, is the case in point. For example, the authorities may be promoting an idea that the best strategic option for the country is to emphasize its belonging to 'Central Europe,' while many/most of the people will rather see themselves as the part of 'Europe.' Second, people's informal vision of the 'proper' area may be to a large degree a continuation of the way this area was imagined in informal discourses of the previous periods, in this case not only the communist times but also earlier eras. The point is to examine the legacies of informal, unofficial social imaginings, not just the official ones.

The spirit of contextual holism is to be found in many corners of today's social sciences. After several years of ascendancy, at least some adherents of methodological and theoretical universalism, either of statistical or game theoretical variety, are beginning to accept the necessity of a dialogue with the 'contextualists.' They seem to be realizing that in order to have an impact on the world of policy making, advice needs to be tailored to specific conditions that are shaped by (specific) history, embedded in (specific) social situations, and framed by (specific) cultures, at least sometimes articulated and practiced at the level of the area. Many area experts, who share at least some premises of contextual holism, are at the same time interested in making general contributions to global or at least inter-regional bodies of knowledge, for example by engaging in comparative projects with scholars studying other areas. ${ }^{15}$ The task is not easy, as the logic of contextualizing pushes a researcher toward the detail, while the logic of comparison calls for at least some measure of abstraction, but it is exactly this tension that provides intellectual energy for the practitioners of Area Studies.

In Table 1 I provide a summary of the argument developed in the rest of the essay. Following the methodological directives derived from contextual holism, I will examine various ways in which area can be conceptualized, imagined, visualized, and employed in practice to direct people's actions. The analysis begins in the third column - culture. Here I define various ways of imaging the area situation. In column four I am trying to identify the ideas and images that have powerful political consequences as they influence the strategic thinking of influential political actors. The fifth column contains my attempts to find the concepts of the area that play role in economic analyses. But before I proceed with my examination, the key concept of this essay - the area as the situation - is introduced and briefly analysed. 
Table 1: principles of contextual holism and Central Europe as an area

\begin{tabular}{|c|c|c|c|c|}
\hline Principle & $\begin{array}{l}\text { Principle as tool of } \\
\text { 'capturing' the area } \\
\text { situation }\end{array}$ & $\begin{array}{l}\text { Culture/ } \\
\text { constructivism }\end{array}$ & Politics & Economy \\
\hline Relationism & $\begin{array}{l}\text { Defining the area } \\
\text { situation via (the } \\
\text { images of) internal } \\
\text { and external networks }\end{array}$ & $\begin{array}{l}\text { Existential in- } \\
\text { betweenness: } \\
\text { Does Central } \\
\text { Europe exist? }\end{array}$ & $\begin{array}{l}\text { Strategic in- } \\
\text { betweenness: } \\
\text { between 'The } \\
\text { West' and } \\
\text { Russia } \\
\text { Remedies: } \\
\text { Intermarium } \\
\text { Visegrád Four }\end{array}$ & $\begin{array}{l}\text { Center-semi- } \\
\text { periphery- } \\
\text { periphery } \\
\text { dynamics } \\
\text { Low- } \\
\text { innovativeness, } \\
\text { 'second class' } \\
\text { economies }\end{array}$ \\
\hline \multirow{2}{*}{ Historicism } & $\begin{array}{l}\text { Legacies as tools of } \\
\text { defining the area } \\
\text { situation }\end{array}$ & $\begin{array}{l}\text { 'Auschwitz' } \\
\text { versus 'Gulag' - } \\
\text { legacies of two } \\
\text { totalitarianisms }\end{array}$ & $\begin{array}{l}\text { Legacies of } \\
\text { totalitarian/post- } \\
\text { totalitarian } \\
\text { institutions }\end{array}$ & $\begin{array}{l}\text { Legacies of } \\
\text { command } \\
\text { economy: Homo } \\
\text { Sovieticus }\end{array}$ \\
\hline & $\begin{array}{l}\text { Critical junctures that } \\
\text { impact the area } \\
\text { situation }\end{array}$ & $\begin{array}{l}\text { Memory wars } \\
\text { over game- } \\
\text { changing events } \\
\text { (commemorating } \\
\text { the fall of } \\
\text { communism) }\end{array}$ & $\begin{array}{l}\text { Imposition of the } \\
\text { Soviet-style state } \\
\text { socialism }\end{array}$ & $\begin{array}{l}\text { 'Shock therapy' } \\
\text { (differential } \\
\text { impact of } \\
\text { neoliberalism) }\end{array}$ \\
\hline Scale & $\begin{array}{l}\text { Sub-national } \\
\text { perspectives on the } \\
\text { area situation }\end{array}$ & $\begin{array}{l}\text { Glocal } \\
\text { identification } \\
\text { (Specific regional } \\
\text { imaginings of the } \\
\text { area) }\end{array}$ & $\begin{array}{l}\text { Region-area } \\
\text { nexus as a rival } \\
\text { of nation-state }\end{array}$ & $\begin{array}{l}\text { Regions as } \\
\text { economic actors } \\
\text { collaborating with } \\
\text { areas }\end{array}$ \\
\hline $\begin{array}{l}\text { Focus on } \\
\text { formal/ } \\
\text { informal } \\
\text { hybrids }\end{array}$ & $\begin{array}{l}\text { Hybridity typical for } \\
\text { the area situation }\end{array}$ & $\begin{array}{l}\text { Cultures of } \\
\text { informality }\end{array}$ & $\begin{array}{l}\text { (Mild case of) } \\
\text { nomenklatura } \\
\text { capitalism }\end{array}$ & $\begin{array}{l}\text { Corruption/ } \\
\text { informality }\end{array}$ \\
\hline
\end{tabular}

Throughout the essay I employ a mix of what anthropologists call the 'emic' and 'etic' approaches. The former instructs the researcher to look at the world through the eyes of the people s/he studies, 'from the native's point of view' in Clifford Geertz's memorable phrase. The basic question is whether the cultural construct of an 'area' plays a role in cultural worlds from within which people think about and act in the world. The etic approach relies on the researcher's own concepts, in order to find the 'objective' determinants of emic concepts, images, and discourses. Since every 'area' is a cultural construct that has a specific genealogy, structure, and meaning, such an investigation is hard to conduct in abstracto; it must begin with studying the 
ways a specific area is imagined, often in competing discourses proposed by individuals, groups and organizations whose discursive work is influenced by the factors that remain outside of their control, for example the geo-political location. My example is the area variably referred to as 'Central Europe,' 'Mitteleuropa,' or 'Intermarium,' and a handful of other terms. I will examine how the way the area has been imagined and named by various actors, mostly in the period that followed the fall of communism in 1989. Since both spatial and temporal contexts matter in such an examination, my application of contextual holism includes some thoughts on post-communist transformations. I will not attempt to review the massive literature in several disciplines and languages; I will merely discuss several examples, mostly drawn from Polish sources, needed to illustrate my contention that contextual holism is a useful tool for a systematic and critical examination of Area Studies.

\section{Area as the situation}

In what sense is 'area' the situation? What are the factors determining or at least influencing the manner in which people define their situation as having something to do with an area, not just locality, a nation-state, or the 'globe'? In order to answer these questions I will use the tools of contextual holism. The directive of constructivism dictates that I privilege the emic approach, so the investigation begins with the images and concepts constituting an area that vie for dominance in native culture(s). I will provide some examples of how both the 'natives' themselves and/or others construe the cultural parameters of the natives' collective existence in terms of an area, by attributing to it certain cultural traits and providing specific interpretations of economic and political realities that impact the functioning of the area. ${ }^{16}$ Discourses actors propose are heavily influenced by historically established ways of thinking as well as institutional and material realities that encourage or discourage people to construe their situation in terms of an area. Moreover, actors not only discursively construct the world around them, but they also act in order to establish or maintain institutions. For the sake of brevity, I will group these historical, material, institutional, and action-oriented factors into political and economic categories and examine them with the help of the four remaining epistemological directives of contextual holism. This method helps not only to organize the analysis, but it also allows to detect some attributes of an 'area' in this case Central Europe - that may not be otherwise noticed.

'Central Europe' serves well as a model for such an exercise, for there exists massive literature on this concept/image, its cultural attributes, its geographical referents, and its potential as a discursive template for building networks. One strand in this literature touches upon a key issue of Area Studies: the inherently unstable nature of the very concept or image of the area. For example, much intellectual energy has been spent on trying to answer the question whether Central Europe actually exists and I suspect there have been similar discussions about other areas. ${ }^{17}$ But this question is ill posed. An area is first of all a discursive construction that is developed and used intensely by some actors, moderately by others, and totally neglected by yet another group. Some actors are 'natives;' some others are more or less influential 'outsiders.' There are periods when a given understanding of an area becomes salient in cultural and political debates, yet at other times its role is negligible or absent. Thus, in accordance with the Thomas Theorem the task is not to determine 'objectively' if a given area exists, but to study what happens when some actors construe their situation in terms of a specific definition of 'their' area and compete, socially and politically, with other actors who may be using another concept or not 
using any conception of the area at all. Moreover, the terms of such debates change, as identities are fluid, also because 'others' may be modifying their definitions of 'us,' often with powerful social and political consequences. ${ }^{18}$ As the Hungarian writer Péter Esterházy noted, after 1989 he was treated first as an 'East European,' then a 'Central European,' then a 'New European,' and finally a 'Non-core European.' 19

According to Polish historian Antoni Podraza, ${ }^{20}$ the concept of Central Europe was first used systematically at the beginning of the twentieth century, though early references are to be found in the writings of Friedrich List, an influential historical economist who wrote foundational texts not only on economic nationalism, but also on the Central European economic area. ${ }^{21}$ Discussed by historians, social scientists, essayists, and writers, the concept indicates the existence of a culturally distinct entity endowed with specific traits to be found neither in the 'West' nor in the 'East.' ${ }^{2}$ There are, of course, various, sometimes conflicting, conceptualizations and imaginings of Central Europe and its attributes, but one thing is certain: attempts to articulate this area's distinctiveness have never gone out of fashion. ${ }^{23}$

There is one conception of this area's identity, once influential, that did loose its lustre: Mitteleuropa. The centre of gravity of the whole area signified by this concept was the powerful culture of the German-speaking world. The conception has several versions, two being most important: predominantly imperialistic 'Prussian' and multi-cultural 'Habsburg., ${ }^{24}$ But the main gist of the idea seems to have always been imperial, certainly as propagated by the most influential proponents of this specific conceptualization of the area: Partsch and Naumann. ${ }^{25}$ The rise of Nazism, World War II, and the Holocaust totally destroyed the usability of this construction; the rise of the Iron Curtain made its revival impossible for a long while. After 1989 and the German reunification a few authors began contemplating the idea's revival, but it does not seem to have caught up. ${ }^{26}$

To summarize, the concept of Central Europe has played an important role in historical debates for quite some time. It has also functioned as a meaningful tool for cultural and political entrepreneurs building internal networks and mobilizing publics for political and economic initiatives. This latter role has come to the fore of important debates in and about the region when the image/concept of Central Europe was turned into an instrument helping to establish and cultivate dissident networks. ${ }^{27}$ This particular usage was brought to the attention of Western intellectual audiences in the mid-1980s, mostly thanks to two influential essays published in The New York Review of Books, by Milan Kundera and Timothy Garton Ash. ${ }^{28}$

\section{Relationism and networks}

From a constructivist perspective relationism postulates looking for various ways in which people imagine and then conduct their collective existence as networked, both internally and externally. An area is thus seen as a situation that facilitates building internal networks of cooperation, but also locks its inhabitants, at least potentially, in larger external networks of partnership, dominance, or dependence. When a given area is seen as solidly articulated and central in a given network it is predisposed to be dominant; when it is construed as unstable and peripheral it often ends up being dependent. To analyse the situation of Central Europe in terms of networks I rely 
on three conceptual tools: existential in-betweenness, strategic in-betweenness, and the centresemi-periphery-periphery triad.

The kind of in-betweenness that for the lack of a better term I call existential has several versions, but all of them suggest an area caught between two other areas that are more powerful politically and more self-confidently articulated, 'the East' and 'the West,' or Russia and Western Europe. The concept indicates that the collective existence of the area inhabitants is pervaded by the sense of indeterminacy and endangerment. Situated neither in the West nor in the East, the area is defined positively as having its own, unique cultural substance or negatively as not being a part of either of other areas. In-betweenness is related to the situation of cultural inchoateness that sometimes is seen as a source of creative and original insights into the mysteries of the human condition (Gombrowicz, Musil, Kafka, Broch, Hašek), but often is construed as debilitating weakness and a source of the inferiority complex. The more crisply articulated cultures, including the Russian, are looked at with envy, fear, but also with contempt or hatred. Even the area's 'high' culture, once the source of its claim to continental dominance or at least parity with 'high' cultures of other areas, has proven to be an unreliable defence against the reoccurring existential doubt. Kundera, in the arguably most influential essay on this conundrum, first reminds us of the extraordinary eruption of cultural creativity in Central Europe at the beginning of the twentieth century, but then observes that by mid-1980s the area ended up in a situation best described as tragedy. Unexpectedly, he sees its main root not in the damage inflicted by the Soviet domination, but in the Western incomprehension of a place where 'true' cultural values, including the cultivation of literary excellence or philosophical debate - gradually forgotten in the West have still being so important that they even nourished anti-Soviet revolts. ${ }^{29}$

An area whose situation is defined, both in self-images and external categorizations, in terms of in-betweenness and proneness to existential trembling, can be easily presented as a legitimate target of conquest in the discourses of political entrepreneurs representing more self-confident areas. When in-betweenness is not just a topic of cultural and literary musings, but enters the geopolitical thinking of various foes of the area, the sense of endangerment becomes one of the key elements of the definition of the situation. For people who see themselves as Central Europeans this is a well-known condition. How can it be ameliorated? The place to begin is to capture the essence of geopolitical imagining that construes this area as unstable or inconsequential. The inbetweenness of Central European situation is a part-and-parcel of geopolitical thinking about Eurasia I call symmetrical bilateralism. Eurasia is conceptualized here as a space caught in the long-term, titanic conflict between two grand civilizations, Russian and 'Western.' In this view Central Europe does not have its own area identity; it is merely a battleground. Not intentionally, one wants to believe, its people are de facto treated as expandable pieces on the chessboard of a grand geo-political game. Moreover, the two sides of the struggle are seen as essentially very similar, each with its well defined, equally legitimate, and easily comparable interests. Central Europe disappears in this type of thinking; its in-betweenness becomes inconsequentiality. The discursive grip of symmetrical bilateralism on geo-political imaginary can be broken by developing its alter ego: asymmetrical multilateralism. Asymmetry means assuming that the Western and Russian cultural and political systems are sufficiently different from each other to claim that, for example, the political decision-making processes are carried out in both systems according to similar rules of the game. Very few scholars in today's comparative politics doubt the existence of such asymmetry. ${ }^{30}$ To begin with, the West has a complex, composite political system with the preponderance of democratic mechanisms, while Russia's system is increasingly authoritarian. The articulation of interests and identities, including those involved in the geo- 
political thinking about Central Europe (particularly if the Baltic states are included in this concept), is therefore quite different in both systems. Tolstrup carefully analyses this asymmetry and sees Russia as playing the role of a 'black knight' in democratization of the region. ${ }^{31} \mathrm{He}$ scrutinizes the situation in 'Near Abroad' of Russia, particularly in Belarus, Moldova and Ukraine, but given Russia's recent actions to destabilise the situation in Central Europe, the term is applicable here as well.

While the existence of a basic symmetry between the West and Russia when it comes to defining geopolitical interests can be debated, the postulate of multilateralism introduces a radically different political optics than the idea of bilateralism. From a multilateral perspective, interests and identities articulated in the area are seen as sovereign and legitimate, and therefore its representatives in international fora must be treated as partners equal to the 'East' and 'West.' But in order to be able to demand that the area is seen as a legitimate player in a multilateral view of the world, the area's elites need to articulate and realize a uniting vision of commonality of interests and identities that is strong enough to sustain a strategic network of area actors. Do such visions exist? In addition to the idea of Central Europe, cultivated predominantly in artistic and literary circles but also by the younger generation of scholars and practitioners of international relations, ${ }^{32}$ there is a construct of 'Intermarium,' associated with various efforts to signal a distinct geo-political stance and develop a viable strategy for defending area interests, without the German domination inevitably associated with Mitteleuropa as the organizing concept. ${ }^{33}$

Intermarium refers to the area between the Black and Baltic Seas. The actual shape of the area differs in various conceptualizations, but it always incorporates the lands usually designated as Central Europe (Poland, Czechia, Slovakia, and Hungary). The concept, particularly popular among the authors representing the right side of the political spectrum, is based on a sharp distinction between the two 'others' of the Central European area. ${ }^{34}$ As Chodakiewicz, an author of a massive treatise on Intermarium writes: "The most crucial task is to define "East" and "West." There are moral, ideological, cultural, geographical, and geopolitical definitions. For us "the West" consists of the sphere of freedom; "the East" denotes the opposite. ${ }^{35}$ Chodakiewicz notes the tension in the Intermarium's situation, caught between the indeterminacy of its inbetweenness and the status of the easternmost outpost of the Western civilization, but he considers it primarily as:

an eclectic and autonomous outpost of the West. Yet, neither completely of the West, nor of the East, the area retains the characteristics of both. At times, it serves as a Western rampart; at other times as a thoroughfare; and also as a launching pad for aggression both ways; but always as a meeting place for all and sundry. This is where the West and the East meet, interact, complement each other, and, occasionally, clash. This experience makes the Intermarium a sui generis phenomenon. ${ }^{36}$

Chodakiewicz's main goal is to instruct American policy makers that the area defined as Intermarium is definitely not a part of any Russian geo-political conception, for example a portion of the Russian-dominated Eurasia. ${ }^{37}$ It is instead 'an area of coexistence, convergence, and clash of many cultures, [that] has historically been a staunch defender of Western Civilization despite long spells of alien domination. ${ }^{38}$ Its identity has been long in development, but it is essentially linked to Western Civilization with which it shares 'the pluralistic heritage of Greek ethics, Roman law, and Christian religion stemming from Judaism. ${ }^{39}$ It is also an area build on 
the legacies of the multi-cultural and multi-ethnic Polish-Lithuanian Commonwealth that were particularly strongly present in the geo-political thinking of Józef Piłsudski, one of the architects of independent Poland after 1918 and the most dominant political figure on the country's interwar political scene.

The Visegrád Group (Visegrád Four, or V4) is an alliance that was build around ideas similar to Internarium albeit on a smaller scale. Founded at meeting in Visegrád on 15 February 1991, the alliance of the Czech Republic, Hungary, Poland, and Slovakia has had a troubled history, particularly in the 2010s when the electoral victory of right-wing populists in Hungary and Poland started generating tension with the two other partners. Nonetheless, the Group's existence is clearly an expression of thinking among many people in these four countries that they can and do see their situation as defined by belonging to a specific area that they need to cultivate and defend.

In the approaches that emphasise economic rather than political or cultural trajectories of Europe (and the world), Eastern Europe is often construed as an area characterised by historically established backwardness. The issue is controversial and hotly debated, ${ }^{40}$ but the image of backwardness has retained its powerful pull on many minds. Immanuel Wallerstein proposed the most influential analysis of its origins and consequences based on a simple tri-partite model of centre, semi-periphery, and periphery. The concept of semi-periphery is often applied to Central Europe, while, roughly speaking, Eastern Europe is seen as a periphery of the 'West.'

Building partially on the work of Polish historians, particularly Adam Małowist, Wallerstein offered a theory of the developmental dynamic whereby the rise of centres is accompanied by the emergence of semi-peripheries and peripheries in what he called the modern world-system. While looking at Europe, he theorized that in the process culminating in the sixteenth century, the developmental trajectory of Central Europe, encompassing in his work East Elbia, Poland, Bohemia, Silesia, Hungary, and Lithuania, ${ }^{41}$ veered off from the common European pattern, as the area experienced the 'manorial reaction' and eventually its main economic engine, agriculture, came to be dominated by a set of labour relations known as 'second serfdom.' 42 As this system took root, the divergence of the Eastern and Western parts of the continent intensified and, eventually, the West emerged as the system's economic (and political) centre, while the various sub-regions of the 'East' began sliding to the status of its semi- or full peripheries. The idea of the peripheral or semi-peripheral status of Central Europe, as well as its causes and consequences, have since been extensively debated in many works on the region. It is the subject of an influential volume edited by Daniel Chirot, where Peter Gunst, for example, carefully reconstructs the pattern of agricultural relations that sets Central Europe (in his work called East Central Europe) from both Western and Eastern Europe. ${ }^{43}$

Recently, several younger scholars in the area, perhaps most prominently Tomasz Zarycki, produced nuanced studies that rely extensively on the categories of centre, semi-periphery and periphery. Zarycki writes almost exclusively about Poland - one of the volumes he edited is simply titled Poland as a Periphery - but he clearly sees this country as representative of the broader Central European situation. ${ }^{44}$ And going beyond Wallerstein, he examines not only economic but also political and cultural dimensions of (semi)peripheriality. What is particularly interesting in these studies are attempts to determine whether the area situation of the places like Poland or Central Europe is better captured as periphery or semi-periphery. Or, what kind of 
periphery a given area is. So, for example, Poland can be construed as an internal periphery vis-àvis the Western centre, while Russia is an external periphery. For the actors in the area, such classificatory exercises have very serious political consequences. As Zarycki observes, in several areas of the world there are projects designed to solidify their images as semi-peripheries, as such a taxonomic location makes it easier to realize the ultimate goal of emerging as an alternative centre. He notes such a desire in the area, associated for example with the concept of Intermarium, although he sees it as less ambitious and crisp than a similar attempt organized by the BRICS countries. Partially, the reason for this limited success may be related to the fact that Intermarium seems to be attractive for only one side of the political spectrum. It is, in Zarycki's view, 'articulated with increasing frequency by conservative political forces, thus Eurosceptic, particularly clearly in Poland and Hungary.' 45

Finally, Zarycki employs effectively Stein Rokkan and Derek Urwin's distinction between interface and external peripheries. ${ }^{46}$ Interface peripheries are peripheral vis-à-vis two centres. It is thus an idea similar to my concept of in-betweenness and as such, together with the concept of semi-periphery, it is a robust conceptual tool for analysing the area situation, certainly when applied to Central Europe. The concept in-betweenness connotes a potentially creative ambiguity that may help produce exceptional works of art and literature and thus assert distinct identity. The concept of interface periphery signals a different potentiality: under certain circumstances such a situation may be economically beneficial as both centres compete to show that they are 'good' masters. It is the situation of the Benelux countries or Switzerland. But as I observed earlier, briefly reviewing Tolstrup's work, when the competing centres have different interests in the peripheral area the effects may be detrimental rather than beneficial. Such is the situation of Central Europe, where Russia, relatively weak economically, is seen by many people as projecting its political power via various destabilising actions, while the West is usually seen as offering economic assistance (via the European Union) and strategic stability (via NATO).

\section{Historicism}

As noted earlier, I assume that there are four specific methodological directives associated with the principle of historicism. Each helps to illuminate a different dimension of the construction of an area image or concept. First, the consideration of the relative weight of 'historical' and 'contemporary' factors in the explanation of 'today's' salience and features of areas such as Central Europe may help to explain the depth of the concept's attractiveness. Second, there is a related issue of determining the length of causal chains in explaining the persistence of specific image or concept of the area ${ }^{47}$ This is related to the study of legitimizing claims of having 'old' or even 'ancient' historical roots. ${ }^{48}$ Third, it is helpful to properly historicize the studied phenomena and reconstruct the actors' cultural worlds from within which a given image of the area has emerged. That helps to observe the evolution in the structure and meaning of the image or concept. Fourth, while studying the formation of legacies, it is worthwhile to begin with a distinction between material, institutional, and cultural legacies, and emphasize that the latter are not simply inherited from the past, but constructed by the actors acting in the present.

It seems that 'Central Europe' belongs to those concepts that are constantly reinvented by various individual and collective actors, ranging from literary scholars to experts on foreign relations and politicians. Its contemporary elaborations are multiple; it is an image or concept that is very much 
'alive.' It does not have a long history, as its first appearance is dated to the mid 19th century, but the process of formation of specific economic, political and cultural features, usually attributed to the area, has been much longer.

The manner in which a discursive construct, for example a specific concept or vision of an area, is articulated and implemented and how effectively it mobilizes people is partially determined by the understandings of the world characteristic of a historical period in which it is all happening. In the introductory part of the essay I summarized Schmitter and Karl's argument that during the regime consolidation phase, the elites that initiated the process may have less control than during transition. A few years ago experts started arguing that the Central European liberal-democratic elites, often having dissident pedigree, presided over political consolidation that brought those countries into the ranks of 'regular' democracies. Given the recent rise of right-wing populist governments, particularly in Hungary and Poland, this argument has been challenged. Among the causes of what is seen by most observers as a serious turbulence in democratic consolidation, if not backsliding, is the idea that previous, predominantly liberal, elites botched the earlier stages of consolidation. As a result, the tenuous elite consensus of the early years of consolidation is gone, the elite is intensely fragmented, and there is a mobilization of new civil society actors who challenge many conceptualizations previously taken for granted in the dominant liberal political culture. The meaning of 'Central Europe' is hotly contested again, as new and often non-elite actors propose its reconceptualization. Under communism and during the early years of transition and consolidation, the concept served to separate the area from the 'East' and create a cultural bridge to the 'West.' In the 2010s, in some new discourses - usually coming from the right - it has been used to separate the area from the 'West,' assert its political sovereignty, and underscore its cultural superiority as a carrier of 'unspoiled' European values. As I pointed out earlier, Chodakiewicz envisions a similar role for 'Intermarium,' a concept that suggests a way of looking at the area that is both culturally distinct and politically sovereign. ${ }^{49}$ There are also proposals for re-conceptualising or reimaging of Intermarium by explicitly counterpoising it to the political imaginary suggested by the concept of Central Europe. ${ }^{50}$

According to the Merriam-Webster Dictionary, a legacy is 'something transmitted by or received from an ancestor or predecessor or from the past.' As I argued in my earlier work, in order to grasp the essence of cultural legacies we need to focus not on 'received from' but rather 'transmitted.' Whereas material legacies - and, to a large extent, institutional legacies as well exist independently of the will and designs of most actors, cultural legacies must be transmitted and cultural scenarios embedded in them must be enacted by at least some of them. In short, cultural legacies are 'real' only insomuch as they inform (cause) actors' behaviour.

Material legacies have been often used to mark the boundaries of Central Europe. Many authors point out the existence of a specific architectural style, for example of the train stations and the particular ambiance of urban spaces. ${ }^{51}$ While material legacies have a layer - their materiality that exists independently of the interpretive work of cultural entrepreneurs, cultural legacies are fully constructed. Their constructed or invented nature is apparent when we think about the emergence or invention of a historical memory (a form of cultural legacy), that had been earlier poorly articulated or non-existent. ${ }^{52}$ One such legacy, quite central to the articulation of the specific Central European experience of World War II, is the construction that compares or even equates the suffering inflicted by the Nazi's with that caused by the Soviets. Many intellectuals and politicians from the area argue that only this part of Europe suffered from both 
totalitarianisms and this fact needs to be properly reflected in the emerging, common historical memory of the whole continent. While this idea is often rejected in the West, it is rather uncontroversial in Central Europe and the Baltic countries. Droit, for example, discusses the complexities of formulating common European memory under the heading of 'the Holocaust and the Gulag in opposition. ${ }^{53}$

Scholars engaged in an intense debate on the nature and consequences of the totalitarian system's legacies grapple also with the question to what degree these legacies set apart the post-communist area from other areas of the world. And some writers make distinctions between the subtypes of post-communist legacies and see the Central European experience as sufficiently different from, say, the experience of the Soviet Union or Yugoslavia. ${ }^{54}$ That sense of a least partially different way in which communism was practiced in Central Europe is invoked to define the specificity of the Central Europe, both by natives and external observers.

Finally, there is the concept of Homo Sovieticus (HS), a model of the human being ostensibly common to the whole post-communist area, thus attributed also to Central Europe. This is a vision of the human being unable to function in democracy and market economy due to the illformed habits developed under communism. The study of HS brings to the front the problem of regions (sub-areas), as the experience of communism was not uniform and people's coping strategies varied, depending on the opportunities created by a specific version of state socialism. I have not conducted a study designed to detect a Central European sub-type of HS, but strongly suspect that such a generalised cultural syndrome might have never existed. In my own study of two regions of Poland I demonstrated that the general Polish pattern of HS is largely a fiction, as the differences in the situations of various subnational regions were often quite pronounced. I suspect that the variety of coping strategies with the deficiencies of state socialism, embedded in and encouraged by specific regional cultures, was so extensive that looking for a Central European model of Homo Sovieticus is futile. ${ }^{55}$

For historicism an area is constructed not only as a legacy of processes or series of events, but also of critical junctures or singular tipping points. These concepts seem to be particularly effective in the study of area as the situation. Do 'the natives' of an area share historical memories of specific events? What are the candidates for such events in the area of Central Europe? The Soviet takeover? The fall of communism? In a study Michael Bernhard and I designed and carried out with a group of colleagues we investigated the manner in which the fall of communism was commemorated on the twentieth anniversary of the event. ${ }^{56}$ The Central European states of Slovakia, the Czech Republic, Poland and Hungary were the cases in the study. No common Central European pattern emerged. Actually, one of the surprising conclusions of our work was the existence of several patterns. Poland and Hungary, two countries that extricated themselves from communism via negotiations and in many ways had been initially the 'leaders' of post-communist transformations, ended up with what we called fractured memory regimes when it came to the collective remembering of the fall of communism. Slovakia also had a fractured memory regime, but here the main source of fracturing was ethnicisation of politics. In the Czech Republic we identified the only pillarized memory regime in the whole studied group. Its main feature is relative tolerance for the co-existence of different memory regimes.

The legacy of the Soviet conquest at the end of World War II, understood as a tipping point, is quite central for shaping the political imaginary of Central Europe, particularly Poland, the area's 
largest country. By contrast to other parts of Europe conquered by the Soviets, in this part of the continent the intensity of armed resistance to the Soviet takeover was relatively high and its memory constitutes one of the cornerstones of the area's specificity.

When it comes to the post-1989 economic trajectory, the introduction of the neo-liberal economic reforms constitutes a truly momentous tipping point. While not all countries emerging from state socialism opted for their most radical version, dubbed 'shock therapy', the Central European quartet did. As a result the (economic) situation of Central Europe has been characterized in terms that set this area apart from other post-communist areas. For example, in an influential study Bohle and Greskovits classify the economic system in the Visegrád countries (as noted above one popular conceptualizaiton of the area under study) as embedded neoliberalism. Its dominant feature is 'a permanent search for compromises between market transformations and social cohesion in more inclusive but not always efficient systems of democratic governement. ${ }^{57}$

\section{Scale}

Does a given concept of the area, cultivated in elite discourses, penetrate other layers of culture? Do, for example, regional cultures articulate with the dominant area concept, such as 'Central Europe'? In my own fieldwork in Cieszyn Silesia, a region whose culture is strongly influenced by Protestantism, I never heard people relating their regional situation to the area situation defined in terms of Central Europe, although they often were quite articulate and knowledgeable about the broader historical and geo-political context impacting their region. The broader concept that I heard several times was 'the Habsburg legacy', best exemplified by a man who once told me: 'From here it is closer to Vienna than Warsaw.' There is a literature on the phenomenon that can be best described as 'unevenness' of the state. Borderlands have often ambiguous identities and their inhabitants may not be as attached to nation-states as their co-nationals living in more central regions of the country. It is there where people tend to construe their situations as complex, multivalent and sometimes related to a transnational conception of an area, rather then a nation-state. Such non-national imagining of collective identity often becomes an object of political battles, as the adherents of such identities draw ire of nationalist politicians and intellectuals for whom the national identity trumps all other attachments. Border areas are also places where people think about their 'economic location' as a part of networks that do not need to be national, but transnationally defined sometimes with the help of an area concept.

\section{Informalfformal hybrids}

'The literature on informality is grounded in geographical, socio-cultural and political-economic areas,' writes Ledeneva, but the massive Global Encyclopaedia of Informality she just published with a team of collaborators, concludes that even if patterns of informality cluster spatially, they do so in a manner that does not necessarily correspond to the map of nation-states. ${ }^{58}$ Nor does it seem to correspond neatly to the division of the world into areas such as, for example, Central, Western or Eastern Europe. While there is an extensive literature on the exceptional role informal practices, usually referred to as 'corruption,' played under state socialism and have continued to play after 1989 in post-communist societies, it does not make a distinction between, say Central and Eastern Europe. Several authors have written about the cultures of corruption, but they also 
do not see a specific Central European pattern of informality. ${ }^{59}$ The literature on nomenklatura capitalism and oligarchy does suggest, however, that in Central Europe, presumably due to some of its historically shaped cultural features and the nature of the transitory process, in which the counter-elites hailing from dissident movements managed to contribute to the establishment of a relatively well functioning system of checks and balances, these phenomena are not as detrimental as in Eastern Europe, particularly Russia. ${ }^{60}$

\section{Conclusions}

Using the directives of contextual holism (constructivism, relationism, historicism, attention to scale, and focus on formal-informal hybrids) I proposed a novel way of looking at Area Studies. Instead of organising my analysis around the theoretical and methodological issues prompted by the word 'studies,' my departure point was 'area.' I reconstructed several conceptions various actors, both 'natives' and outsiders, have used to define a part of the European continent in terms of the concept/image of Central Europe and several related concepts. To what degree my results are applicable to other areas needs to be determined. Only careful studies of the natives' own imaginings of their situations in terms of an 'area' can provide an answer. But the lessons of this study should be helpful in examining the grip other area concepts/images have on the social and political imagination of people living in other parts of the world.

Let me summarize the directives that can be applied in the studies of other areas. The directive of relationism calls for reconstructing the role the 'area' or 'area situation' plays as a guiding image or concept in actors' efforts to construct networks of cooperation or to respond to being 'networked' by other, often more powerful, external actors. First, the situation of an area should be analysed in terms of its existential and geo-political status in a broader system of areas (inbetween, peripheral or central) and its consequences. Second, the economic dimension of the area situation can be fruitfully analysed with the help of the Wallersteinian centre-semi-peripheryperiphery triad, the centrepiece of his world system (global) theory. Consistent with the philosophy of constructivism, the primary task is to identify the communities of discourse that produce such diagnoses, determine their relative power in domestic and international political fields, and finally try to assess the social, political, cultural, and economic implications of formulating and disseminating specific concepts and images of a given area situation.

The postulate of historicism directs the researcher attention to the impact the legacies of both processes and critical junctures may have on people's proclivity to construe their situation in terms of an area. Among the questions that may be usefully asked are: What are specific material, institutional, and cultural legacies through which people cultivate their self-definitions in terms of an area situation? What are the events that are central in collective memory that sustain the image of collective existence as in some important sense related to the area situation?

While considering the significance of scale, one is prompted to examine imaginings and/or concepts of the area that emerge in sub-national, regional cultures. The definition of the situation of a given nation state in terms of an area that is proposed, say, by the central government may not be shared by the elites of various regions whose cultures may have distinct trajectories that are not easily reducible to the overarching 'national' narrative typically propounded by the central 
government. A question one may want to ask is: What tensions do exist between the imaginings of the area by central and local elites of a given nation state?

Finally, there is a set of issues that arise if the researcher studies not only official, formal forms of cultural production, but looks also for informal (sub)cultures and specific patterns in which the two mesh in formal-informal hybrids. The distinction is particular important in non-democratic situations where official visions of the governments may be quite distinct from the visions circulating at various levels of informal cultural production in the society. The questions that come to the fore here include: What are the area specific combinations of formal and informal imaginings of the area? How are they constructed in influential discourses of self-identity?

There are three main lessons from my exercise. First and most important is that 'areas' and 'Area Studies' have certainly not been invented exclusively by Western scholars and policy makers, who - we are often told - created this approach ab nihilo to build a detailed knowledge of the world and who, at least in some cases, have been driven by instrumental considerations of the Cold War. Quite the contrary, 'Central Europe,' 'Mitteleuropa,' 'Intermarium' and other related concepts or images have turned out to be powerful discursive building blocs of the 'native' social and political imaginary in this part of Europe. The second main lesson is that in order to define and practice Area Studies, while taking the concept/image of 'area' seriously, the researcher must develop deep, multi- and often inter-disciplinary knowledge of the relevant part of the world, built on the 'natives' own understandings and conceptualizations of their situation. Third, in order to reconstruct the manner in which the concept is employed it is advisable to examine the widest possible range of situations, to determine when and how the concept or image of area is employed. I suggest that the tools derived from the approach I called contextual holism can be very useful to systemitise such an investigation.

\section{NOTES}

${ }^{1}$ William I. Thomas, Dorothy Swaine Thomas, The Child in America: Behavior Problems and Programs (New York: Knopf, 1928), p. 572. For a thorough discussion of the Theorem's origins and proper attribution see Robert Merton, 'The Thomas Theorem and "The Matthew Effect", Social Forces 74, 2, (1995), pp. 379-424. ${ }^{2}$ Robert E. Park and Ernest Burgess in a treatise regarded as the foundational work of symbolic interactionism write: 'common participation in common activities implies a common definition of the situation.' In fact, every single act, and eventually all moral life, is dependent upon the definition of the situation. A definition of the situation precedes and limits any possible action, and a redefinition of the situation changes the character of the action.' Introduction to the Science of Sociology (Chicago, The University of Chicago Press, 1921), p. 764. ${ }^{3}$ Znak 11, 12 (1987), pp. 390-391.

${ }^{4}$ This task is, of course, at the centre of many major theoretical works. The most influential is, arguably, Anthony Giddens' theory of structuration. Efforts to overcome the structure-agency dichotomy are also vigorous in various versions of new institutionalism. See James Mahoney and Kathleen Thelen (eds), Explaining Institutional Change: Ambiguity, Agency, and Power (Cambridge: Cambridge University Press, 2009).

${ }^{5}$ Michael McFaul, 'The Missing Variable: The "International System" as the Link between Third and Fourth Wave Models of Democratization', in Valerie Bunce, Michael McFaul, and Kathleen Stoner-Weiss (eds), Democracy and Authoritarianism in the Postcommunist World (Cambridge: Cambridge University Press, 2010), p. 9.

6 'It is the doctrine that transactions, interactions, social ties, and conversations constitute the central stuff of social life'. See Charles Tilly and Robert E. Goodin, 'It Depends', in R. E. Goodin and C. Tilly (eds), The Oxford Handbook of Contextual Political Analysis (Oxford: Oxford University Press), p. 11. This chapter 
provides a useful explication of the 'relational' ontological position and contrasts it to other ontologies of the social. See also F. Bönker, K. Müller, and A. Pickel, 'Cross-Disciplinary Approaches to Postcommunist Transformation: Context and Agenda,' in F. Bönker, K. Müller and A. Pickel (eds), Postcommunist Transformation and the Social Sciences (Lanham: Rowman and Littlefield, 2002), p. 24.

${ }^{7}$ Schmitter and Karl, 'The Conceptual Travels', pp. 175-6.

${ }^{8}$ Ibid., p. 176.

${ }^{9}$ Additionally, the concept of agency needs to be carefully reconsidered because people's ability to affect the world varies and depends on the whole set of factors. As Mahmood argues, 'if the ability to effect change in the world and in oneself is historically and culturally specific (both in terms of what constitutes 'change' and the means by which it is effected), then the meaning and sense of agency cannot be fixed in advance, but must emerge through an analysis of the particular concepts that enable specific modes of being, responsibility, and effectivity.' Saba Mahmood, Politics of Piety. The Islamic Revival and the Feminist Subject (Princeton:

Princeton University Press, 2005), pp. 14-15.

${ }^{10}$ Grzegorz Ekiert and Stephen E. Hanson (eds), Capitalism and Democracy in Central and Eastern Europe. Assessing the Legacy of Communist Rule (Cambridge: Cambridge University Press, 2003).

${ }^{11}$ I wrote on the construction of legacies in Jan Kubik, 'Cultural Legacies of State Socialism: History-making and Cultural-political Entrepreneurship in Postcommunist Poland and Russia', in G. Ekiert and S. E. Hanson (eds), Capitalism and Democracy, pp. 317-51.

${ }^{12}$ Basudeb Guha-Khasnobis, Ravi Kanbur and Elinor Ostrom. Linking the Formal and Informal Economy. Concepts and Policies (Oxford: Oxford University Press, 2006).

${ }^{13}$ Natalia Letki and Geoffrey Evans, 'Endogenizing Social Trust: Democratization in East-Central Europe', British Journal of Political Science 35 (2004), p. 518.

${ }^{14}$ William. L. Miller, Åse. B. Grødeland, and Tatyana. Y. Koshechkina. A Culture of Corruption. Coping with Government in Post-communist Europe (Budapest: Central European University Press, 2001).

${ }^{15}$ For a nuanced analysis of how such contributions are made and what ethical and political issues are involved see Michael Kennedy, Globalizing Knowledge. Intellectuals, Universities, and Publics in Transformation (Stanford: Stanford University Press, 2014).

${ }^{16}$ Identities are always constructed via a complex interplay of 'self-identification and the identification and categorization of oneself by others.' Rogers Brubaker and Frederic Cooper, 'Beyond Identity', Theory \& Society 29, 1 (2000), p. 15.

${ }^{17}$ See, for example Jeremy Eades, 'The Development of Asia Pacific Studies: A Case Study of Internationalization in Japanese Higher Education', in T. Wesley-Smith, J. Goss (eds), Remaking Area Studies. Teaching and Learning across Asia and the Pacific (Honolulu: University of Hawai'i Press, 2010).

${ }^{18}$ Western academics often treat 'areas' as concepts exclusively or predominantly created and used in the discourses of Western academic and policy-making establishments. The role of 'native' constructions is ignored or marginalised. See, for example, Ian Klinke, 'Area studies, geography and the study of Europe's East', The Geographical Journal, 181, 4, (2015), pp. 423-426.

${ }^{19}$ Péter Esterházy, 'How Big is the European Dwarf?', in D. Levy, M. Pensky, J. Torpey (eds), Old Europe, New Europe, Core Europe. Transatlantic Relations After the Iraq War (London 2005), s. 74.

${ }^{20}$ See Antoni Podraza, 'Europa Środkowa jako region historyczny,', 2004, http://jazon.hist.uj.edu.pl/zjazd/materialy/podraza.pdf (accessed 5 February 2018). Podraza relies here on Jacques Droz's L'Europe Centrale. Evolution historique de l'idee de Mitteleuropa (Paris, 1960). For an English version of this essay see Antoni Podraza, 'Central Europe as a Historical Region,' in Jerzy Kłoczowski (ed), Central Europe Between East and West (Lublin, 2005).

${ }^{21}$ On List see Roman Szporluk, Communism and Nationalism. Karl Marx versus Friedrich List (Oxford: Oxford University Press, 1988). Buchowski and Kołbon also emphasise the significance of Liszt's ideas and date the beginning of their influence to 1841. See Michał Buchowski and Izabela Kołbon, 'Od "Mitteleuropy" do Europy Środkowej. Zarys dziejówidei,' Sprawy Narodowościowe. Seria nowa, 19 (2001), p. 15.

${ }^{22}$ I am sidestepping a discussion among historians on whether the concept of 'East Central Europe' is more adequate. It tends to be privileged by Polish historians, while their Hungarian and Czech colleagues tend to stick to 'Central Europe.' Among the historians writing in English, Joseph Rothschild's magisterial work is entitled East Central Europe between the World Wars (Seattle and London: University of Washington Press, 
1974). Johnson, by contrast, writes about Central Europe. See Johnson, Lonnie R., Central Europe Enemies, Neighbors, Friends (Oxford: Oxford University Press, 1996).

${ }^{23}$ Marta Cobel-Tokarska and Marcin Dębicki, Stowo i terytorium. Eseje o Europie Środkowej (Warszawa; Wydawnictwo Akademii Pedagogiki Specjalnej, 2017).

24 'The notion of Mitteleuropa carries diverse connotations, many far from positive. It should be noted that the Mitteleuropa fondly recalled by Habsburg-era nostalgics stands in clear oppositions to the Prussian understanding of Mitteleuropa. The Habsburg multi-national vision is a negation of the Prussian state-centric ideal first promoted by Friedrich Naumann and others, and later adopted by Nazi geopoliticians'. Luiza Bialasiewicz, 'Back to Galicia Felix?', in C. Hann and P. R. Magocsi (eds), Galicia. A Multicultured Land (Toronto: University of Toronto Press, 2005), p. 178.

${ }^{25}$ Josef F. M. Partsch, Mitteleuropa. Die Länder und Völker von den Westalpen und dem Balkan bis an den Kanal und das Kurische Haff (Gotha: Justus Perthes, 1904). Friedrich Naumann, Mitteleuropa (Berlin: G. Reiner, 1916).

${ }^{26}$ Anna Sosnowska offers an interesting set of comments on 'Mitteleuropa versus Central Europe.' Available at https://www.aspenreview.com/article/2017/mitteleuropa-versus-central-europe/ (accessed 3 January 2018).

${ }^{27}$ See Weronika Parfianowicz-Vertun, Europa Środkowa w tekstach i działaniach. Polskie i czeskie dyskusje (Warszawa: Wydawnictwa Uniwersytetu Warszawskiego, 2016). Bialasiewicz observes: 'During the Cold War, the geographical imagination of Mitteleuropa enabled Polish, Czech, and Hungarian dissidents and literary dreamers to leap outside of the closed spaces of the bi-polar divide and place themselves in the West.' Luiza Bialasiewicz, 'Back to Galicia Felix, p. 163.

${ }^{28}$ Milan Kundera 'The Tragedy of Central Europe', The New York Review of Books, 26 April, 1984 and Timothy Garton Ash, 'Does Central Europe Exist?', The New York Review of Books, 9 October 1986. Todorova emphasizes the role of the area authors, Jenő Szücs, Czesław Miłosz and Milan Kundera. See Maria Todorova, Imagining the Balkans (New York: Oxford University Press, 1997), p. 141.

${ }^{29}$ Kundera, ibid.

${ }^{30}$ See, for example, Henry Hale, Patronal Politics. Eurasian Regime Dynamics in Comparative Perspective (New York: Cambridge University Press, 2015).

31 'Russia's goals in the region seem to be incompatible with those of the West, and this means that the possible positive influence that, for example, the EU, NATO, or the US, can exert in the area is actively counterbalanced and maybe even 'crowded out' by the negative influence of Russia.' Jakob Tolstrup, 'Studying a negative external actor: Russia's management of stability and instability in the "Near Abroad", Democratization, 16,5 (2009), p. 940. See also Jacob Tolstrup, Russia vs the EU: The Competition for Influence in Post-Soviet States (Lynne Rienner Publishers, 2013).

32 Zlatko Šabic, Petr Drulak (eds), Regional and International Relations of Central Europe (Basingstoke: Palgrave Macmillan, 2012).

${ }^{33}$ Buchowski and Kołbon, 'Od "Mitteleuropy",' p. 21.

${ }^{34}$ It was an organizing concept for several groups of dissidents in the 1980s in Poland. See, for example, Buchowski and Kołbon, ibid., p. 22.

${ }^{35}$ Marek Jan Chodakiewicz, Intermarium: The Land between the Black and Baltic Seas (New Brunswick, NJ, Transaction Publishers. 2012). A thorough, critical review of this book was written by David Katz and published in Israel Journal of Foreign Affairs VII, 2, 2013. Accessed at http://defendinghistory.com/wpcontent/uploads/2013/03/Dovid-Katz-review-of-Intermarium-in-Israel-Journal-of-Foreign-Affairs-7-22013.pdf. In the Polish language, it received a book-length treatment from another prominent figure of the right, Leszek Moczulski.

${ }^{36}$ Chodakiewicz, ibid, 16.

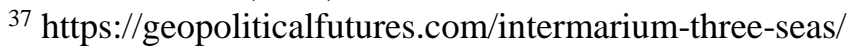

${ }^{38}$ Chodakiewicz, Intermarium, 16.

${ }^{39}$ Ibid, 19.

${ }^{40}$ Anna Sosnowska, Zrozumieć zacofanie. Spory historyków o Europę Wschodnia (1947-1994). See also 'Why is Eastern Europe Backward,' Aspen Review 04/2013 https://www.aspenreview.com/article/2017/why-iseastern-europe-backward/ (accessed 3 February 2018). 
${ }^{41}$ Immanuel Wallerstein, The Modern World-System. Capitalist Agriculture and the Origins of the European World-Economy in the Sixteenth Century (New York: Academic Press, 1974), p. 94.

${ }^{42}$ Wallerstein, ibid., p. 95

${ }^{43}$ Peter Gunst, 'Agrarian systems of Central and Eastern Europe', in D. Chirot (ed.), The Origin of

Backwardness in Eastern Europe (Berkeley: University of California Press, 1989).

${ }^{44}$ See in particular, Tomasz Zarycki, 'Polska jako peryferie stykowe,' in T. Zarycki (ed.), Polska jako peryferie

(Warszawa: Wydawnictwo naukowe Scholar, 2016).

${ }^{45}$ Ibid., p. 106.

${ }^{46}$ Stein E. Rokkan and Derek W. Urwin, Economy, Territory, Identity: Politics of West European Peripheries

(London: Sage, 1983).

${ }^{47}$ Grzegorz Ekiert and Stephen E. Hanson (eds), Capitalism and Democracy in Central and Eastern Europe. Assessing the Legacy of Communist Rule (Cambridge: Cambridge University Press, 2003).

${ }^{48}$ Arjun Appadurai, 'Past as a Scarce Resource', Man, New Series 16, 2 (June) (2001), pp. 201-19.

${ }^{49}$ Such ideas have broader circulation, also outside of the area. Friedman, for example, writes: 'The governments in Poland and Hungary are anathema to the multilateral, collectivistic framework of the EU, and Brussels has criticized them accordingly. But neither Warsaw nor Budapest has given in to EU demands. The Intermarium therefore is more than a military alliance.' See George Friedman, 'Reality Check. From the Intermarium to the Three Sees, 7 July, 2017. Available at https://geopoliticalfutures.com/intermarium-threeseas/ (accessed 3 January 2018). Anna Sosnowska offers an interesting set of comments on 'Mitteleuropa versus Central Europe.' Available at https://www.aspenreview.com/article/2017/mitteleuropa-versus-centraleurope/ (accessed 3 January 2018).

${ }^{50}$ See, for example, Anna Sosnowska on 'Mitteleuropa versus Central Europe.' Available at https://www.aspenreview.com/article/2017/mitteleuropa-versus-central-europe/ (accessed 3 January 2018).

51 'Much of Central Europe possesses a similar cultural landscape and may be regarded as one cultural area. Common cultural links are visible if one looks at the architecture of cities which were once part of the AustroHungarian Empire. Whether it is Brno in Moravia, Bratislava, Vienna, Budapest, Krakow, Lviv, Ljubljana, or peripheral Chernivtsi in Ukraine, one may find the same type of theatre architecture, similar city halls and railway stations from about 1900'. See Monika Murzyn, 'Heritage Transformation in Central and Eastern Europe', in P. Howard and B. Graham (eds), The Ashgate Research Companion to Heritage and Identity (Aldershot: Ashgate, 2008), p. 317.

52 The phenomena covered by the concept of cultural legacies share many features with the concept of historical memory.

${ }^{53}$ Emmanuel Droit, 'The Gulag and the Holocaust in Opposition: Official Memories and Memory Cultures in an Enlarged Europe', Vingtième Siècle. Revue d'histoire 2, 94 (2007), pp. 101-20. See also Marek Kucia, 'The Europeanization of Holocaust Memory and Eastern Europe', East European Politics and Societies 20, 1 (2016), pp. 97-119.

54 '.... the prospects for democratization and democratic deepening were significantly better in countries with favorable legacies (such as the relatively developed, ethnically homogenous countries of East Central Europe with their longer histories of statehood, democracy, and bureaucratic competence) than in many of the fledgling new states emerging from the former Soviet Union and Yugoslavia.' See Grigore Pop-Eleches, 'Historical Legacies and Post-Communist Regime Change,' The Journal of Politics, 69, 4 (2007), 909.

${ }^{55}$ Myron Aronoff and Jan Kubik, Anthropology and Political Science: A Convergent Approach (Oxford: Berghahn Books, 2013). See in particular my chapter 'Homo Societicus and Vernacular Knowledge'.

${ }^{56}$ Michael Bernhard and Jan Kubik (eds), Twenty Years After Communism: The Politics of Memory and Commemoration (New York: Oxford University Press, 2014).

${ }^{57}$ Dorothee Bohle and Bela Greskovits, Capitalist Diversity on Europe's Periphery (Ithaca: Cornell University Press, 2012), p. 3.

${ }^{58}$ Alena Ledeneva with A. Bailey, S. Barron, C. Curro and E. Teague (eds), The Global Encyclopaedia of Informality Understanding Social and Cultural Complexity, Volume 1 (London: UCL Press, 2018), p. 21.

59 William L. Miller, Åse B. Grødeland, Tatyana Y. Koshechkina (eds), A Culture of Corruption? Coping with Government in Post-Communist Europe (Budapest and New York: CEU Press, 2001). 
${ }^{60}$ Ion Marandici, Oligarchic State Capture: Wealthy Elites and State Autonomy in Communist and Postcommunist Countries, PhD Dissertation, Rutgers University, 2017.

\section{BIBLIOGRAPHY}

Appadurai, Arjun, 'Past as a Scarce Resource', Man, New Series 16, 2 (June) (2001), pp. 201-19.

Aronoff, Myron and Jan Kubik, Anthropology and Political Science: A Convergent Approach (Oxford: Berghahn Books, 2013).

Ash, Timothy Garton, 'Does Central Europe Exist?', The New York Review of Books, 9 October 1986.

Bernhard, Michael and Jan Kubik (eds), Twenty Years After Communism: The Politics of Memory and Commemoration (New York: Oxford University Press, 2014).

Bialasiewicz, Luiza, 'Back to Galicia Felix?', in C. Hann and P. R. Magocsi (eds), Galicia. A Multicultured Land (Toronto: University of Toronto Press, 2005).

Bohle, Dorothee and Bela Greskovits, Capitalist Diversity on Europe's Periphery (Ithaca: Cornell University Press, 2012).

Bönker, F., K. Müller, and A. Pickel, 'Cross-Disciplinary Approaches to Postcommunist Transformation: Context and Agenda,' in F. Bönker, K. Müller and A. Pickel (eds), Postcommunist Transformation and the Social Sciences (Lanham: Rowman and Littlefield, 2002).

Brubaker, Rogers and Frederic Cooper, 'Beyond Identity', Theory \& Society 29, 1 (2000).

Buchowski, Michał and Izabela Kołbon, ‘Od “Mitteleuropy” do Europy Środkowej. Zarys dziejów idei,’ Sprawy Narodowościowe. Seria nowa, 19 (2001).

Chodakiewicz, Marek Jan, Intermarium: The Land between the Black and Baltic Seas (New Brunswick, NJ, Transaction Publishers. 2012).

Cobel-Tokarska, Marta and Marcin Dębicki, Stowo i terytorium. Eseje o Europie Środkowej (Warszawa; Wydawnictwo Akademii Pedagogiki Specjalnej, 2017).

Droit, Emmanuel, 'The Gulag and the Holocaust in Opposition: Official Memories and Memory Cultures in an Enlarged Europe', Vingtième Siècle. Revue d'histoire 2, 94 (2007), pp. 101-20.

Droz, Jacques, L'Europe Centrale. Evolution historique de l'idee de Mitteleuropa (Paris, 1960).

Eades, Jeremy, 'The Development of Asia Pacific Studies: A Case Study of Internationalization in Japanese Higher Education', in T. Wesley-Smith, J. Goss (eds), Remaking Area Studies. Teaching and Learning across Asia and the Pacific (Honolulu: University of Hawai'i Press, 2010).

Ekiert, Grzegorz and Stephen E. Hanson (eds), Capitalism and Democracy in Central and Eastern Europe. Assessing the Legacy of Communist Rule (Cambridge: Cambridge University Press, 2003). 
Esterházy, Péter, 'How Big is the European Dwarf?', in D. Levy, M. Pensky, J. Torpey (eds), Old Europe, New Europe, Core Europe. Transatlantic Relations After the Iraq War, (London 2005).

Friedman, George, 'Reality Check. From the Intermarium to the Three Sees' https://geopoliticalfutures.com/intermarium-three-seas/

Guha-Khasnobis, Basudeb, Ravi Kanbur and Elinor Ostrom, Linking the Formal and Informal Economy. Concepts and Policies (Oxford: Oxford University Press, 2006).

Gunst, Peter, 'Agrarian systems of Central and Eastern Europe', in D. Chirot (ed.), The Origin of Backwardness in Eastern Europe (Berkeley: University of California Press, 1989).

Hale, Henry, Patronal Politics. Eurasian Regime Dynamics in Comparative Perspective (New York: Cambridge University Press, 2015).

Johnson, Lonnie R., Central Europe Enemies, Neighbours, Friends (Oxford: Oxford University Press, 1996).

Kennedy, Michael, Globalizing Knowledge. Intellectuals, Universities, and Publics in Transformation (Stanford: Stanford University Press, 2014).

Klinke, Ian, 'Area studies, geography and the study of Europe's East', The Geographical Journal, 181, 4, (2015), pp. 423-426.

Kucia, Marek, 'The Europeanization of Holocaust Memory and Eastern Europe', East European Politics and Societies 20, 1 (2016), pp. 97-119.

Kundera, Milan, 'The Tragedy of Central Europe,' The New York Review of Books, 26 April 1984.

Ledeneva, Alena, with A. Bailey, S. Barron, C. Curro and E. Teague (eds), The Global Encyclopaedia of Informality. Understanding Social and Cultural Complexity, Volume 1 (London: UCL Press, 2018).

Letki, Natalia and Geoffrey Evans, 'Endogenizing Social Trust: Democratization in East-Central Europe', British Journal of Political Science 35 (2004).

Mahmood, Saba, Politics of Piety. The Islamic Revival and the Feminist Subject (Princeton: Princeton University Press, 2005).

Mahoney, James and Kathleen Thelen (eds), Explaining Institutional Change: Ambiguity, Agency, and Power. (Cambridge: Cambridge University Press, 2009).

Marandici, Ion, Oligarchic State Capture: Wealthy Elites and State Autonomy in Communist and Postcommunist Countries (PhD Dissertation, Rutgers University, 2017).

McFaul, Michael, 'The Missing Variable: The "International System" as the Link between Third and Fourth Wave Models of Democratization', in Valerie Bunce, Michael McFaul, and Kathleen Stoner-Weiss (eds), Democracy and Authoritarianism in the Postcommunist World (Cambridge: Cambridge University Press, 2010).

Merton, Robert ,'The Thomas Theorem and "The Matthew Effect”", Social Forces 74, 2, (1995), pp. 379-424.

Miller, William L., Åse B. Grødeland, Tatyana Y. Koshechkina (eds), A Culture of Corruption? Coping with Government in Post-Communist Europe (Budapest and New York: CEU Press, 2001). 
Murzyn, Monika, 'Heritage Transformation in Central and Eastern Europe', in P. Howard and B. Graham (eds), The Ashgate Research Companion to Heritage and Identity (Aldershot: Ashgate, 2008).

Naumann, Friedrich, Mitteleuropa (Berlin: G. Reiner, 1916).

Parfianowicz-Vertun, Weronika, Europa Środkowa w tekstach i działaniach. Polskie i czeskie dyskusje (Warszawa: Wydawnictwa Uniwersytetu Warszawskiego, 2016).

Park, Robert E. and Ernest Burgess, Introduction to the Science of Sociology (Chicago, The University of Chicago Press, 1921).

Partsch, Josef F. M., Mitteleuropa. Die Länder und Völker von den Westalpen und dem Balkan bis an den Kanal und das Kurische Haff (Gotha: Justus Perthes, 1904).

Podraza, Antoni, 'Europa Środkowa jako region historyczny' http://jazon.hist.uj.edu.pl/zjazd/materialy/podraza.pdf

Podraza, Antoni, 'Central Europe as a Historical Region,' in Jerzy Kłoczowski (ed.), Central Europe Between East and West (Lublin, 2005).

Pop-Eleches, Grigore, 'Historical Legacies and Post-Communist Regime Change,' The Journal of Politics, 69, 4 (2007).

Rokkan, Stein E. and Derek W. Urwin, Economy, Territory, Identity: Politics of West European Peripheries (London: Sage, 1983).

Rothschild, Joseph, East Central Europe between the World Wars (Seattle and London: University of Washington Press, 1974).

Sosnowska, Anna, Zrozumieć zacofanie. Spory historyków o Europę Wschodnia (1947-1994).

Sosnowska, Anna, 'Why is Eastern Europe Backward,' Aspen Review 04/2013, https://www.aspenreview.com/article/2017/why-is-eastern-europe-backward

Sosnowska, Anna 'Mitteleuropa versus Central Europe.'

https://www.aspenreview.com/article/2017/mitteleuropa-versus-central-europe

Szporluk, Roman, Communism and Nationalism. Karl Marx versus Friedrich List (Oxford: Oxford University Press, 1988).

Šabic, Zlatko, Petr Drulak (eds), Regional and International Relations of Central Europe (Basingstoke: Palgrave Macmillan, 2012).

Thomas, William I., Dorothy Swaine Thomas, The Child in America: Behavior Problems and Programs (New York: Knopf, 1928).

Tilly, Charles and Robert E. Goodin, 'It Depends,' in R. E. Goodin and C. Tilly (eds), The Oxford Handbook of Contextual Political Analysis (Oxford: Oxford University Press).

Todorova, Maria, Imagining the Balkans (New York: Oxford University Press, 1997). 
Tolstrup, Jakob, 'Studying a negative external actor: Russia's management of stability and instability in the "Near Abroad"', Democratization, 16:5 (2009).

Tolstrup, Jacob, Russia vs the EU: The Competition for Influence in Post-Soviet States (Lynne Rienner Publishers, 2013).

Wallerstein, Immanuel, The Modern World-System. Capitalist Agriculture and the Origins of the European World-Economy in the Sixteenth Century (New York: Academic Press, 1974).

Zarycki, Tomasz, 'Polska jako peryferie stykowe,' in T. Zarycki (ed.), Polska jako peryferie (Warszawa: Wydawnictwo naukowe Scholar, 2016). 